\title{
Debt, Agency, and Management Contracts in REITs: The External Advisor Puzzle
}

\author{
DENNIS R. CAPOZZA \\ University of Michigan Business School, Ann Arbor, MI 48109-1234 \\ E-mail: capozza@umich.edu \\ PAUL J. SEGUIN \\ Carlson School of Management, Minneapolis, MN 55455-0430 \\ E-mail: pseguin@csom.umn.edu
}

\begin{abstract}
This study investigates why externally advised real estate investment trusts (REITs) underperform their internally managed counterparts. Consistent with previous studies, we find that REITs managed by external advisors underperform internally managed ones by over 7 percent per year. Property-level cash-flow yields are similar between the two managerial forms, but corporate-level expenses and especially interest expenses are responsible for lower levels of cash available to shareholders in externally advised REITs. We document that the higher-interest expenses are due to both higher levels of debt and to higher debt yields for externally advised REITs. We posit that compensating managers based on either assets under management or on property-level cash flows creates incentives for managers to increase the asset base by issuing debt even if the interest costs are unfavorable.
\end{abstract}

Key Words: agency costs, executive compensation, real estate investment trusts

\section{Introduction}

Recent years have witnessed a rapid evolution in both the legal organization of claims to real estate assets held by investors and in the compensation of managers of these assets. The predominant real estate investment vehicle of the 1980 s, the syndicated real estate limited partnership (RELP), is now relatively rare. In its place, real estate investment trusts (REITs) have burgeoned as the preferred real estate investment vehicle.

The compensation of real estate management has also evolved. Most RELPs were managed by their sponsors, who typically held a 1 percent general partnership interest but whose compensation derived primarily from asset-based or property-income-based management contracts.

Many REITs have been managed by external advisors under contracts similar to those found in the RELPs. Three types of fees are common among external advisor contracts. First and most common are fees based on total assets under management (65 percent of external advisor contracts). Other contracts specify fees as a percent of property-level income (62 percent) (rental income minus property expenses) or as a percentage of transactions volume (55 percent) (e.g., purchases and sales of properties, or issuance of 
mortgages). Advisors often receive more than one type of compensation. These three contract types are neither exhaustive nor mutually exclusive. It is possible for an external advisor contract to include some, all, or none of the three. Our focus is on the 85 percent of external-advisor contracts that are based on either assets or property income or both.

It is now more common for a REIT to be internally managed rather than externally managed. For REITs where internal staff make asset and liability management decisions, manager compensation is typically in the form of salary and performance incentives based on corporate-level rather than property-level cash flows. This parallel existence of alternative types of management contracts and compensation schemes among the publicly traded REITs provides the key design feature of this study. Specifically, the performance of the two classes of trusts, which are essentially identical in every way except for the management compensation structure, provides a unique laboratory for the study of contracts, incentives, and performance.

Further, since most REITs, unlike their RELP predecessors, are publicly traded, they are subject to Security and Exchange Commission disclosure requirements, ensuring the availability of a rich source of financial and asset data. Equity market trading generates a continual flow of information on the financial-asset-market valuation of these assets. As a result, we can perform our study of contracts, incentives, and performance along a number of dimensions.

Our primary focus is on the relationship between organizational form and agency costs. Agency theory argues that incentives can lead to managerial actions that are not optimal from shareholders' perspectives. Misalignment of incentives occurs when managerial compensation packages are structured so that managers have incentives that are not perfectly correlated with maximizing shareholder wealth. Sagalyn (1996) argues that a misalignment of incentives exists for REITs that are managed externally (i.e., managed by advisors), while, with internal management, the potential for conflicts of interest is reduced.

The key distinction between the two managerial arrangements is not the existence or absence of an arm's-length relationship between the manager and shareholders but rather a prevalence of contracts that compensate external advisors based on metrics other than shareholder wealth. Indeed, the majority of external advisors are compensated as a percentage of assets, as a percentage of property-level cash flows, or as a combination of the two.

Using a variety of metrics, we demonstrate that externally managed REITs underperform and are priced at a discount relative to their internally managed counterparts. Shareholders of externally advised REITs realized returns that were more than 7 percent per year below those realized by shareholders of internally managed REITs over the sample period from 1985 to 1992. Further, using our version of Tobin's $q$ (the ratio of the equity-market value to the property-market value of the REITs assets), we demonstrate that underperformance was at least partially anticipated for externally managed REITs.

Our study is not the first to document underperformance for externally managed REITs. Howe and Shilling (1990) demonstrated that externally managed REITs experience negative abnormal returns over the 1973 to 1987 period on average. Hsieh and Sirmans 
(1991) found that "noncaptive", REITs (i.e., those REITs that do not have business relationships with external sponsors or advisors) outperformed captive ones over the 1968 to 1986 period, and Cannon and Vogt (1995) found that internally managed REITs outperformed advisor REITs over their 1987 to 1992 sample period even after adjusting for differences in market risk.

Our study does offer at least two important extensions to these findings. First, unlike the time-series approaches used in previous studies, we augment our analysis with crosssectional analyses based on our variant of Tobin's $q$. We choose $q$ ratios for reasons similar to those expounded by Lang and Stulz (1994, p. 1249), who argue that "By focusing on Tobin's $q$, rather than on performance over time, we avoid some of the problems of the earlier literature ... since $q$ is the present value of future cash flows divided by replacement costs, no risk adjustment or normalization is required to compare $q$ across firms.' Since existing evidence (Finnerty and Park, 1991; Cannon and Vogt, 1995) as well as our results find significant differences in the riskiness of externally managed versus internally managed equity, it is imperative that any measure of relative performance control for these differences. We believe that the use of a $q$-ratio metric provides an exact control.

Our second, and more important, contribution is to identify both the avenue through which managerial structure affects firm valuation and the specific suboptimal behavior of external advisors. We begin with the hypothesis first suggested by Jenkins (1980) and empirically verified by Finnerty and Park (1991) that external advisors would prefer to expand their asset base through the use of leverage. Finding a greater use of debt in the capital structure should not directly lead to a reduction in value. Indeed, the famous Modigliani-Miller capital structure paradigm states that, in a tax-free environment, capital structure should be irrelevant for valuation. However, such a conclusion is predicated on debt contracts that are negotiated at equilibrium interest rates that reflect the riskiness of the debt.

In contrast, we find that externally managed REITs issue debt with promised rates that exceed the rates on debt issued by internally managed REITs. The higher interest rates are not fully explained by a greater use of debt in externally managed REITs. Further, these debt contracts are negotiated at rates that exceed the current yield on projects purchased with the loaned funds. It is the use of debt negotiated at seemingly above market rates that systematically reduces cash flows available to shareholders.

We argue that such suboptimal behavior by managers can be rationalized by examining the bases of their compensation. External advisors are primarily compensated as a percentage of either the total assets under management or the property-level cash flows of the assets. In neither case do interest expenses impact the base for their compensation. Thus, they have little incentive to negotiate for favorable debt rates. Indeed, since issuing debt and using the proceeds to purchase more real assets increases assets and propertylevel cash flows, external managers have incentives to issue debt, regardless of the interest rate. It is this incentive to issue debt combined with the lack of incentive to do so at competitive rates that can lead to a reduction in equity value. Further, we demonstrate that, once differences in interest rates are accommodated, there are no detectable effects of managerial form.

In the following section, we outline the model underlying our estimates. Section 3 
provides a description of the data and variables used in this study. In Section 4, we contrast the performance characteristics of equity claims on externally and internally managed REITs using both time-series and cross-sectional methods. In the time-series regressions we explicitly accommodate for differences in market risk. In the cross-sectional method, using $q$ ratios circumvents the need for risk adjustments. We next examine the impact of managerial form on each of the determinants of cash flows available to shareholders, with an emphasis on debt and interest expenses. In the penultimate section, we investigate whether organizational structure has any remaining effect on relative valuation after controlling for the indirect effects of the abnormally high rates of interest paid. The final section provides a summary and discusses the implications of these findings on optimal managerial contracts.

\section{The model}

The model underlying our empirical specification is the fundamental dividend discount relationship. If $V_{t}$ is the value of a share of stock at time $t, D_{t}$ is the dividend paid at time $t$, and $r$ is the discount rate, we have

$$
V_{t}=\int_{t}^{\infty} D_{t} e^{-r t} d t
$$

For REITs, the cash flow available to be distributed to shareholders, $C_{t}$, is simply the cash flow from properties, $Y_{t}$, minus any interest expense, $I_{t}$, and corporate overhead expenses (general and administrative expenses), $G_{t}$ :

$$
C_{t}=Y_{t}-I_{t}-G_{t}
$$

If REITs pay out 100 percent of corporate-level cash flows, we have (from (1))

$$
V_{t}=\int_{t}^{\infty}\left(Y_{t}-I_{t}-G_{t}\right) e^{-r t} d t
$$

From (3), it is clear that for advisory contracts to affect value or return, the channel must be through at least one of the components of cash flow. Therefore, to trace the impact of management contracts we explore each component separately. It is reasonable to expect each component to depend on total assets, total liabilities, or both. In addition, we hypothesize that the type of management contract, $M$, and a vector of other exogenous variables, $\boldsymbol{X}$, may affect cash flow as well. We can write

$$
\begin{aligned}
Y & =y(A, M, \boldsymbol{X}) \\
I & =i(L, M, \boldsymbol{X}) \\
G & =g(A, L, M, \boldsymbol{X}),
\end{aligned}
$$


where $A$ is total assets and $L$ is total liabilities.

Our empirical strategy is to estimate each of the relationships in (4) to (6) and then test for the significance of management type in the equation for each cash-flow component. By doing so, we will be able to determine the source of the value loss arising from external advisors.

\section{Data and variables}

The database, introduced and described in detail in Capozza and Lee (1995), contains a subset of the REITs listed in the NAREIT (National Association of Real Estate Investment Trusts) source books from 1985 to 1992 . This database contains only equity REITs and excludes all mortgage, hotel, restaurant, and health-care REITs; REITs that do not trade on the NYSE, AMEX, or NASDAQ; and REITs for which property information is not available. These restrictions create a set of 75 REITs, which are listed in Table 1, and a sample of 298 usable annual observations. For each observation, balance sheet, income statement, and property variables were manually extracted from $10 \mathrm{~K}$ reports, annual reports to shareholders, and proxy statements.

The database also provides estimates of the values of the real estate properties held. Property-specific capitalization rates were assigned to each property based on its location and type by Capozza and Lee. They next calculated an individual REIT's average capitalization rate as the weighted average of the component property capitalization rates. Finally, net asset values were estimated by subtracting liabilities from estimated property assets plus other assets. Additional adjustments, where appropriate, were made for joint ventures, differences between coupon rates and market yields on debt, and property turnover.

Estimates of the underlying property market values are of particular interest since they allow us to examine the relationship between equity market values and replacement values with enhanced statistical power. Because the underlying assets-real properties-are traded in a relatively active primary market, we are able to obtain estimates of the replacement cost of assets with much greater precision than previous studies. Since active markets for underlying assets do not exist for the majority of industries, previous studies could only coarsely estimate replacement costs by accumulating historical capital investment and adjusting for inflation and estimated economic depreciation (Lindenberg and Ross, 1981). In contrast, our replacement-cost estimates are based on recent market transactions prices of assets similar to those underlying each REIT.

For this study, the classification of external advisory contracts is of particular interest. For each REIT with an external advisor, $10 \mathrm{Ks}$ were reviewed to determine the basis of compensation. The most common types of fees are fees based on total assets under management (65 percent of external advisor contracts), fees as a percent of property income (62 percent), and fees based on a percentage of transactions volume (55 percent). As indicated earlier it is possible for an external advisor contract to include some, all or none of the three types. Our focus is on the 85 percent of external-advisor contracts that are based at least partly on either assets or property income or both. Most of the remaining 
Table 1. The sample REITs. The sample of REITs, drawn from the equity REIT Database project, are described in Capozza and Lee (1995). This database is constructed from the 1992 NAREIT (National Association of Real Estate Investment Trusts) source book, which lists all publicly traded REITs (209 REITs) as of December 31, 1991. The database excludes all mortgage, hotel, restaurant, and hospital REITs and REITs that do not trade on NYSE, AMEX, or NASDAQ or for which property information is not available. These exclusions lead to a sample of 75 REITs, which are listed here. Given this list, the researchers then attempted to construct one observation per REIT for each of the years between 1985 and 1992. Of the 75 equity REITs, 32 appear in all eight years and are annotated with an asterisk $(*)$, with the remaining appearing for at least one year.

*BRE Properties, Inc.

Berkshire Realty Co., Inc.

*Bradley Real Estate Trust

Burnham Pacific Properties, Inc.

*California Real Estate Investment Trust

Cedar Income Fund, Ltd.

Cedar Income Fund 2, Ltd.

Chicago Dock and Canal Trust

*Clevetrust Realty Investors

*Continental Mortgage \& Equity Trust

Copley Property, Inc.

Cousins Properties, Inc.

Dial Reit, Inc.

Duke Realty Investments, Inc.

*EQK Realty Investors

*Eastgroup Properties

*Federal Realty Investment Trust

*First Union Real Estate Equity and Motgage Investments

Grubb \& Ellis Realty, Inc. Trust

*HRE Properties

*ICM Property Investors, Inc.

*IRT Property Co.

Income Opportunity Realty Trust

Koger Equity, Inc.

Landsing Pacific Fund

Linpro Specified Properties

*MGI Properties, Inc.

*MSA Realty Corp.

*Meridian Point Realty Trust 83

*Meridian Point Realty Trust 84

Meridian Point Realty Trust IV

Meridian Point Realty Trust VI

Meridian Point Realty Trust VII

Meridian Point Realty Trust VIII

*Merry Land and Investment, Inc.

Monmouth Real Estate Investment Corp.

*New Plan Realty Trust

*Nooney Realty Trust, Inc.
*One Liberty Properties, Inc.

PS Business Parks, Inc.

Partners Preferred Yield, Inc.

Partners Preferred Yield II

Partners Preferred Yield III

*Pennsylvania Real Estate Investment Trust

*Property Trust America

*Prudential Realty Trust

Public Storage Properties VI

Public Storage Properties VII

Public Storage Properties VIII

Public Storage Properties IX, Inc.

Public Storage Properties X, Inc.

Public Storage Properties XI, Inc.

Public Storage Properties XII

Public Storage Properties XIV

Public Storage Properties XV, Inc.

Public Storage Properties XVI

Public Storage Properties XVII

Public Storage Properties XVIII

Public Storage Properties XIX

Public Storage Properties XX

*Real Estate Investment Trust Ca

Realty South Investors, Inc.

*Santa Anita Realty Enterprises

Sizeler Property Investors, Inc.

*Trammell Crow Real Estate Investment

*Transcontinental Rlty Investors

*U S P Real Estate Investment Trust

*United Dominion Realty Trust Inc.

Vanguard Real Estate Fund I

Vanguard Real Estate Fund II

Vinland Property Trust

*Washington Real Estate Investment Trust

*Weingarten Realty Investors

*Western Investment Real Estate Trust

Wetterau Properties, Inc. 
contracts ( 75 percent of the remaining 15 percent) could not be classified because the information on the nature of the contract was either missing or undecipherable.

Table 2 contains means of variables used in this analysis for the entire sample $(n=298)$, for the subsample of observations corresponding to REITs with an external advisor compensated with an asset- or income-based fee $(n=99)$, and for the remaining observations where no such structure exists $(n=199)$. The final column contains $t$ statistics associated with the hypothesis that the two subsample means are equal.

A comparison of means of assets and dollar volume provides evidence that externally managed REITs are significantly smaller than their internally managed counterparts. One explanation for this finding may be that smaller REITs do not have an asset base that justifies the attention of a full-time management team. As a result, external (part-time) advisors are selected for these REITs. The weighted-average capitalization rate for internally managed REITs is significantly larger than the average rate for internally managed REITs. Although externally advised REITs have, on average, higher general and administrative (G\&A) expense ratios, this difference is not statistically significant.

However, there is strong evidence that both the use of debt and the interest paid on this debt are significantly larger for externally advised REITs. These two results provide some preliminary support to our assertion that managers who are compensated on an asset- or income-based fee attempt to increase their fees by issuing debt and investing the proceeds into income generating assets.

We also consider two measures of the focus or diversification of the asset base. Our measures of focus are Herfindahl indices based on property type and regional location. The first, property-type Herfindahl, is computed as $\sum_{t=1}^{4} S_{t}^{2}$, where $S_{t}$ is the proportion of a firm's assets invested in each of four real estate types: office, warehouse, retail, or

Table 2. Summary statistics. This table reports means, standard deviations, and extreme values for a number of summary statistics calculated across our sample of 298 observations for 75 firms. Market value of assets is estimated market value of properties plus the book value of other assets. The leverage ratio is defined as total liabilities/(total liabilities + market value of the equity). $q$-ratio is the ratio of market equity (stock price times number of shares) to the market value of properties plus the book value of other assets minus book liabilities (NAV).

\begin{tabular}{lcccc}
\hline Variable & $\begin{array}{l}\text { All Firms } \\
n=298\end{array}$ & $\begin{array}{l}\text { Externally Advised } \\
n=99\end{array}$ & $\begin{array}{l}\text { Internally Advised } \\
n=199\end{array}$ & $\begin{array}{l}t \text {-Test for } \\
\text { Equality }\end{array}$ \\
\hline Market value of assets (\$ mil.) & 176.8 & 90.0 & 219.9 & 5.8 \\
Quarterly dollar volume (\$ mil.) & 131.2 & 60.8 & 162.2 & 5.3 \\
Weighted capitalization rate (\%) & 8.91 & 8.82 & 8.97 & 2.2 \\
G\&A/Total assets (\%) & 1.14 & 1.23 & 1.09 & -1.5 \\
Interest expense/Debt (\%) & 8.05 & 9.00 & 7.59 & -3.3 \\
Corporate cashflow yield (\%) & 8.95 & 8.82 & 9.02 & 0.3 \\
Leverage ratio (\%) & 35.8 & 42.9 & 32.3 & -3.3 \\
Property type Herfindahl (\%) & 66.8 & 62.0 & 69.2 & 2.4 \\
Regional Herfindahl (\%) & 58.2 & 57.1 & 58.8 & 0.5 \\
$q$-ratio & 1.00 & 0.95 & 1.02 & 1.4 \\
\hline
\end{tabular}


apartment. Higher levels of concentration by property type lead to higher levels of the index. If the firm is highly focused along one dimension, the index is close to one; while the index approaches 0.25 , if the firm's portfolio of properties is equally diversified across the four property types. We also compute regional Herfindahl as $\sum_{r=1}^{8} S_{r}^{2}$, where $S_{r}$ is the proportion of a firm's assets invested in each of eight real estate regions: New England, Middle Atlantic, Southeast, Midwest, Plains, Southwest, South Pacific, and North Pacific. As with the property-type Herfindahl variable, this concentration variable can vary from one for a geographically focused REIT to 0.125 for a REIT with holdings equally diversified across the eight regions. There is evidence that internally managed REITs are more focused along both the property type and regional dimensions, but only the propertytype dimension is statistically significant.

Finally, we construct our modified $q$ ratios by dividing the equity-market value of equity by the property-market (replacement) value of properties plus the book value of other assets minus the book value of debt. Other assets and debt are predominantly current assets or liabilities with low durations. Thus, deviations between book and market values for other assets and debt tend to be small. While we recognize that these estimates of value contain measurement error, we believe they are the most sophisticated available. Further, given the homogeneity of the assets and the methodology employed, we posit that our estimates of property-market values of assets are economically less noisy than those used in other studies to estimate Tobin's $q$, which are usually based on the depreciated accounting cost of assets. Using this univariate technique, there is weak evidence $(p>1)$ that internally advised REITs are priced at a larger multiple of their underlying assets than externally advised ones.

\section{Results: Performance and relative valuation}

In this section, we pursue two empirical objectives. First, we examine whether the asset- or income-based externally managed REITs underperformed their internally managed counterparts over our sample period. Similar to earlier studies (Howe and Shilling, 1990; Hsieh and Sirmans, 1991; and Cannon and Vogt, 1995), we demonstrate that underperformance exists within our subsample using ex post analyses. However, unlike past studies, which use a stock-market index, we control for both market and industry risk by using a real estate market index to proxy for differences in risk levels or exposures. Results are qualitatively similar if only a stock-market index is included. Second, in contrast to past studies, we supplement our analyses by using ex ante measures of anticipated future performance. Using $q$ ratios, the ratio of the stock-market value of assets to the underlying property-market value of assets, we are able to extract expectations of future performance. Differences between the stock-market value and the property-market values of assets reflect the expected impact of management or organizational form on value. Further, since there is a relatively active market for the underlying real assets in this industry, such measures of the effects of management on value will be more accurate than similar measures calculated for other industries (Capozza and Seguin, 1998b; Bradley, Capozza, and Seguin, 1998). 


\subsection{Ex post performance measures}

To examine the impact of management structure on realized returns, we follow the lead of previous studies and examine returns using a single-factor model. However, in contrast to these studies, we do not use the returns to a well diversified portfolio of industrial equities but instead use as our factor the returns to a portfolio of REITs: the NAREIT index. By relating returns to the industry index rather than the market index, the common factor among these firms is more efficiently extracted, and the precision of estimates is improved.

In the first column of Panel A of Table 3, we report estimates of the single-factor model using all observations. The coefficient associated with the index is insignificantly different from unity, suggesting that the riskiness of our sample is equal to the average riskiness of the universe of publicly traded REITs. The intercept coefficient is negative and significant, however, suggesting that our sample, as a whole, underperformed the universe. In the second column, we allow the intercept to vary between internally and externally managed trusts. The intercept, which is an estimate of the relative performance of internally managed REITs, is negative but insignificantly different from zero, suggesting that these trusts performed as well as the universe. In contrast, the coefficient associated with an externally managed REIT is significantly negative and suggests that the subsample of externally managed REITs underperformed the internally managed universe by 7.1 percent per year.

There is evidence in this and other studies, however, that the amount of financial risk (leverage) differs between the two classes of trusts. As a result, estimating a single risk coefficient may result in a misspecification. To mitigate this problem, we allow the slope coefficient to vary between internally and externally managed trusts. The results, presented in the next two columns of Table 3, suggest that externally managed REITs have higher levels of systematic risk, but the coefficients estimating the differences in this risk are not reliably greater than zero. However, the indicator associated with externally managed trusts remains significantly negative.

In the second panel, we investigate the source of the higher risk associated with externally managed REITs. Specifically, we investigate whether externally managed REITs have greater risk due to higher business risk (i.e., they choose riskier projects) or due to higher financial risk (i.e., greater leverage). To do so, we use the fact that equity betas equal asset betas multiplied by a leverage factor, or.

$$
\beta_{\text {equity }}=\beta_{\text {assets }}(1+\text { Debt/Equity }) \text {. }
$$

Substituting this into the single-factor model speicification yields

$$
R_{j t}=\alpha+\beta_{\text {assets }}(1+\text { Debt/Equity }) R_{\text {NAREIT }} .
$$

In Panel B of Table 3, therefore, we regress observed returns on the product of the NAREIT index returns and the leverage factor. The coefficient associated with this product can be interpreted as an asset beta. The results in the first column of this panel 


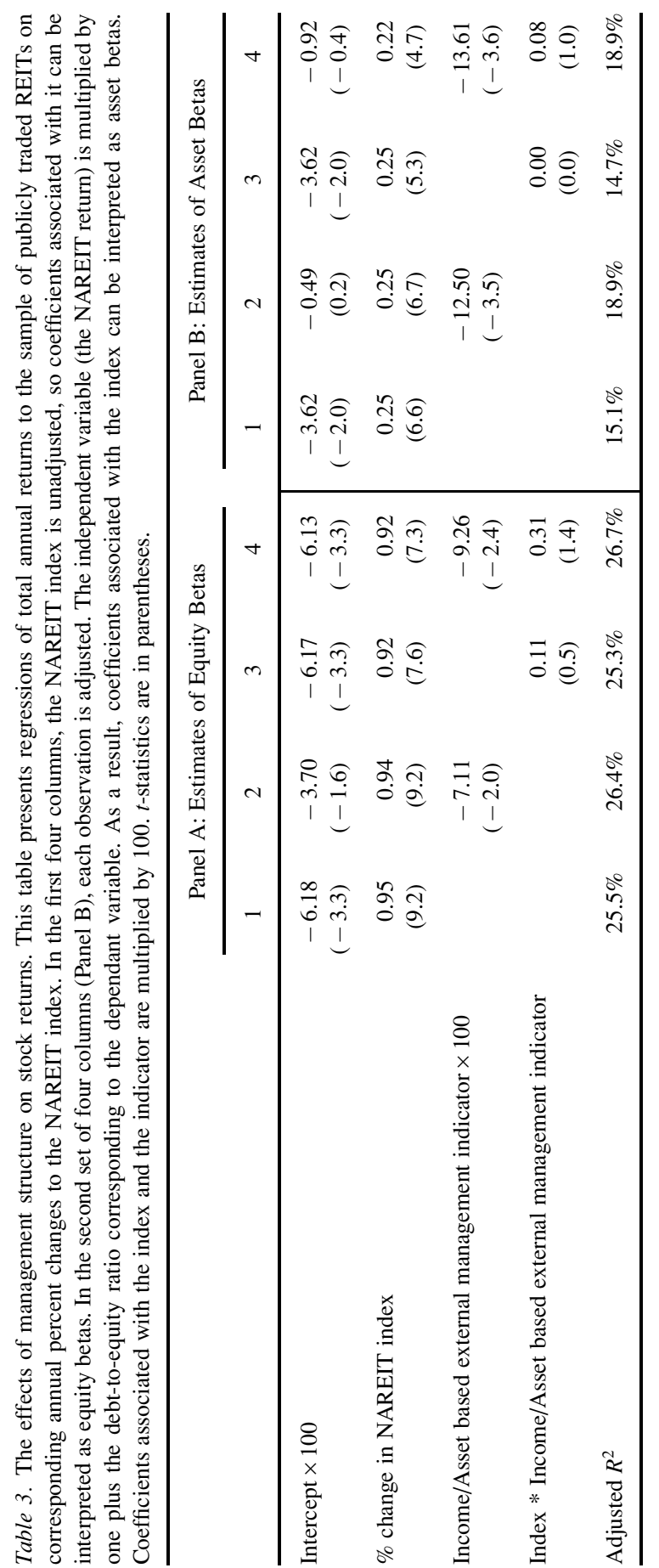


indicate that the typical asset beta is around 0.25 . The intercept is negative and significant, suggesting that the REITs in our sample underperformed, on average, by about 3.6 percent per year. In the second column, we again allow the intercept to vary between the two classes of trusts. The intercept is now insignificantly different from zero, suggesting that the internally managed trust in our sample performed as well as the universe. In contrast, the coefficient associated with the externally managed trusts is significantly negative. Further, the coefficient suggests that these trusts underperformed by over 12 percent per annum.

In the final two columns, we allow the asset beta to vary between the two classes of trusts. However, in neither specification is this difference statistically or economically meaningful. This result suggests that the higher level of risk associated with externally managed trusts in this and previous studies can be completely attributed to higher financial risk. There is no evidence that externally managed trusts systematically choose projects with higher business risk (asset risk).

Most important, however, the coefficient associated with the underperformance of externally managed REITs remains negative and significant. Indeed, the magnitude of this coefficient suggests that the externally managed REITs in our sample underperformed their internally managed counterparts by over 13 percent per year, a remarkably poor performance by any standard.

\subsection{Ex ante performance measures}

In the previous subsection, we documented that externally managed REITs underperformed their internally managed counterparts. As indicated above, this underperformance has been documented previously. However, none of the earlier studies has investigated whether the impact of external management on cash flows is anticipated. To do so, we investigate ex ante measures of relative valuation.

The first column of Table 4 presents estimates of a specification where our modified $q$ ratio is regressed against a series of annual intercepts. As discussed in the data section, the dependent variable is a $q$ ratio defined as the equity-market value of equity divided by the net replacement value of equity. The denominator is calculated by adding the propertymarket value of the real estate assets and the book value of other assets and then subtracting the book value of debt. Since this first specification contains only annual intercepts, the estimated coefficients can be interpreted as annual averages of the ratio. These averages declined from their peak in 1987 until 1991. This decline can be attributed to equity-market agents correctly anticipating declines in property-market values due to overbuilding throughout the 1980s (see Hendershott and Kane, 1995).

The second equation in Table 4 includes an indicator variable that equals one if the firm is externally managed based on an income- or asset-related fee. The coefficient indicates that the equity-market value of these firms is discounted by 7 percent. Next, we consider the two compensation structures individually. Unfortunately, such analysis is hampered by the high degree of correlation between the two structures. Specifically, of the 72 observations with an income-related fee and 76 observations with an asset-based fee, 49 
Table 4. Management structure and $q$ ratios. The dependent variable is the ratio of the Wall Street value of equity to the difference between the property-market value of assets and the book value of debt. Estimation is by ordinary least squares. Indicator variables capturing calendar year are used as intercepts. Property-type focus is a Herfindahl coefficient generated by summing the squared proportions of a firm's assets invested in each of four real estate types. Regional-focus is, similarly, a Herfindahl index computed across eight geographic regions. $t$ statistics are in parentheses. The $F$-test for joint significance tests whether the two coefficients associated with the two management indicators are simultaneously equal to zero, while the $F$-test for equality tests whether the two coefficients associated with the two management indicators are equal to each other. Asterisks indicate whether these test-statistics exceed the $10 \%(*), 5 \%(* *)$, or $1 \%(* * *)$ critical values.

\begin{tabular}{|c|c|c|c|c|c|}
\hline & Equation (1) & Equation (2) & Equation (3) & Equation (4) & Equation (5) \\
\hline 1985 & 1.01 & 1.03 & 1.03 & 0.93 & 0.93 \\
\hline 1986 & 1.11 & 1.14 & 1.14 & 1.04 & 1.05 \\
\hline 1987 & 1.16 & 1.19 & 1.19 & 1.07 & 1.08 \\
\hline 1988 & 1.04 & 1.07 & 1.07 & 0.97 & 0.98 \\
\hline 1989 & 1.03 & 1.06 & 1.06 & 0.96 & 0.97 \\
\hline 1990 & 1.00 & 1.02 & 1.01 & 0.91 & 0.91 \\
\hline 1991 & 0.87 & 0.89 & 0.89 & 0.79 & 0.80 \\
\hline 1992 & 0.89 & 0.90 & 0.90 & 0.82 & 0.83 \\
\hline Income/Asset based external management & & $\begin{array}{c}-0.07 \\
(-2.3)^{* *}\end{array}$ & & $\begin{array}{c}-0.07 \\
(-2.2)^{*}\end{array}$ & \\
\hline Asset-based external management & & & $\begin{array}{l}-0.07 \\
(-1.8)\end{array}$ & & $\begin{array}{c}-0.07 \\
(-1.7)^{*}\end{array}$ \\
\hline Income-based external management & & & $\begin{array}{c}-0.02 \\
(-0.5)\end{array}$ & & $\begin{array}{c}-0.01 \\
(-0.3)\end{array}$ \\
\hline Property-type focus & & & & $\begin{array}{c}0.02 \\
(0.4)\end{array}$ & $\begin{array}{c}0.02 \\
(0.4)\end{array}$ \\
\hline Regional focus & & & & $\begin{array}{c}0.08 \\
(1.5)\end{array}$ & $\begin{array}{c}0.08 \\
(1.5)\end{array}$ \\
\hline Dollar volume/equity & & & & $\begin{array}{c}0.03 \\
(1.3)\end{array}$ & $\begin{array}{c}0.03 \\
(1.3)\end{array}$ \\
\hline Adjusted $R^{2}$ & 0.13 & 0.15 & 0.15 & 0.15 & 0.15 \\
\hline$F$-test for joint significance & & & $3.14 * *$ & & $2.40^{*}$ \\
\hline$F$-test for equality & & & 1.00 & & 0.06 \\
\hline
\end{tabular}

have both, leading to a correlation between these variables in excess of 0.55 . The results of this colinearity can be seen in column 3: the significance of the individual coefficients is reduced, and yet they remain jointly significant. Further, we cannot reject the null that the two coefficients equal each other, consistent with the belief that the choice between income-based and asset-based does not differentially impact valuation. 


\subsection{Robustness tests}

To test the robustness of these findings, we alter the specification to account for assetbase focus and equity liquidity. Capozza and Seguin (1998b) examine $q$-ratio measures for REITs and argue that focus affects relative value through liquidity. Following their lead, we include two dimensions of asset focus (regional focus and property-type focus) and a measure of liquidity (annual equity turnover). Consistent with their conjectures, our results show that more focused and more liquid REITs have higher $q$-ratios. Further, the three variables are jointly significant $\left(F=6.78>F_{(3, \infty, 0.99)}=3.78\right)$.

However, despite the inclusion of these additional explanatory variables, our primary conclusions are unchanged. In equation (4), the significant coefficient associated with the single indicator variable suggests that these forms of managerial contracts reduce relative value by about 7 percent. Further, in equation (5), the two individual indicators remain jointly significant, and we again cannot reject the null that the two coefficients are equal.

As mentioned above, the dependent variable in these regressions is the ratio of the equity-market valuation of equity to the property-market or replacement value of the equity. We reestimated the same five specifications using a ratio of asset values. Such a transformation is accomplished by adding the value of debt to both numerator and denominator. Not surprisingly, our conclusions are invariant with an estimated wealth loss of 7 percent associated with this organizational structure.

We further examined specifications with stock-market values of either assets or equity as the dependent variable and property-market values of the corresponding variable as an independent variable. An estimate of a relative discount can be constructed by adding as an additional independent variable the product of the indicator variable with the propertymarket variables. Although not reported, we estimated a number of variants that accommodated focus and liquidity. Regardless of the specification, there was a statistically significant discount in stock-market valuation that ranged from 7 percent to 15 percent. The smallest (in an absolute value sense) $t$-statistic was -2.8 .

We therefore conclude, based on the analyses performed in this section, that the external-advisor structure reduces the wealth of shareholders and that this wealth reduction is partially anticipated. That is, current share prices are discounted to reflect the anticipated wealth loss or lower cash flows available to shareholders. However, since investors who purchased equity claims even at these discounted values suffered underperformance during the sample period, we conclude that, in our sample period, the anticipation was incomplete and that the discount in share price was insufficient to offset the underperformance during the sample period. We next turn to an investigation of the avenues through which asset- or income-based external management results in inferior performance.

\section{Sources of underperformance}

In this section, we examine financial data for our sample and test the two fundamental hypotheses of our study: (1) whether incentive contracts based on property income or 
assets induce external managers to increase the base of their compensation by issuing debt and using the proceeds to invest in properties and (2) whether they do so regardless of whether they must pay supernormal interest costs.

\subsection{Management structure and the use of debt}

We investigate the relationship between management form or compensation and capital structure by examining financial leverage while controlling for the underlying asset base. In our initial specification, which appears as equation (1) in Table 5, we regress the average of the book values of debt at the beginning and end of the fiscal year on the average of the property-market (replacement) value of assets at the beginning and end of the fiscal year. There are no intercepts in these regressions, but estimation is by weighted least squares, with the average asset variable used as a weight. As a result, the coefficient can be interpreted as the (weighted) average debt-to-assets or, equivalently, debt-to-debtplus-equity ratio. The coefficient indicates that this average is 35 percent, which is comparable to the average reported in Table 2 .

To determine the impact of the structure/compensation, we allow the leverage ratio to vary with the external management indicator. To do so, we extend the initial specification above:

$$
\text { Debt }=\beta \text { Assets }+\varepsilon,
$$

Table 5. Management compensation form and leverage. The dependent variable is the average of the book values of debt at the beginning and end of the fiscal year. Assets are the average of the property-market or replacement value of assets at the beginning and end of the fiscal year. Estimation is by weighted least squares, with the average asset variable used as a weight. There are no intercepts in these regressions. Property-type focus is a Herfindahl coefficient generated by summing the squared proportions of a firm's assets invested in each of four real estate types. Regional-focus is, similarly, a Herfindahl index computed across eight geographic regions. $t$ statistics are in parentheses. All coefficients are multiplied by 100. Asterisks indicate whether these test-statistics exceed the $10 \%(*) 5 \%(* *)$, or $1 \%(* * *)$ critical values.

\begin{tabular}{lccc}
\hline & Equation (1) & Equation (2) & Equation (3) \\
\hline Average assets & 34.8 & 33.1 & 21.5 \\
& $(25.2)^{* * *}$ & $(22.4)^{* * *}$ & $(4.0)^{* * *}$ \\
Average assets* Income or asset-based external management & 10.9 & 13.2 \\
& & $(2.9)^{* * *}$ & $(3.4)^{* * *}$ \\
Property-type focus & & 16.5 \\
& & & $(2.9)^{* * * *}$ \\
Regional focus & & & 0.3 \\
Adjusted $R^{2}$ & & & $(0.1)$ \\
\hline
\end{tabular}


where $\beta$ is the estimate of leverage by allowing $\beta$ to vary with the indicator:

$$
\beta=\beta_{\text {int }}+\beta_{\text {ext }} \text { (Income- or Asset-Based External Compensation Indicator). }
$$

Substitution of (10) into (9) indicates that the proper specification includes not the indicator itself but the interaction of the indicator with the property-market ("Main Street") value of the assets.

The results appear in the second column. The variable associated with the product of the indicator variable and assets is economically and statistically significant, indicating that externally managed REITs carry 11 percent more debt in their capital structure.

One possibility is that the intrinsic nature of the assets under management differs between the two types of trusts. If, for example, one class of trusts has assets that have a higher collateral value or that are easier to monitor, then such differences must be accommodated. To do so, we follow Capozza and Seguin (1998b) and Bradley, Capozza, and Seguin (1998), who argue that collateral value varies with focus. We employ two proxies for focus, regional and property-type Herfindahl indices, as described in the data section. These variables are included in the third specification of Table 5.

There is evidence consistent with the belief that asset portfolios that are more focused along the property-type dimension provide greater collateral value. The coefficient associated with that focus variable is positive and significant. This result is consistent with the hypothesis that lenders are, ceteris paribus, more willing to make loans backed by focused portfolios. Most important, however, is the coefficient associated with management structure, which remains significant. The point estimate now exceeds 13 percent.

\subsection{Management structure and free cash flow}

In this section we implement the empirical strategy outlined in Section 2 to investigate the role of management structure on cash available to shareholders. We do so by tracing the effect of structure on each line in a REIT's income statement. First, we examine the relationship between incentives and property-level cash flows. We then examine their effects on corporate-level expenses (G\&A expenses) and on interest expenses. We conclude by examining the relationship between management structure and residual or free cash flows.

\subsubsection{Project-level cash flows}

As a baseline model, we regress property-level cash flows-the difference between property-level revenues (rents) and property-level expenses (maintenance, property taxes, utilities, etc.) — on our estimates of the property-market values of the assets held by the REIT. The resulting coefficient is a property level or "gross" yield. This specification is estimated using weighted-least-squares with asset replacement values used as weights and 
allowing for intercepts that vary annually and appears in the first column of Table 6 . The estimated coefficient associated indicates that REITs earn, on average, a gross yield of 8.3 percent, which is consistent with the range of capitalization rates presented in Table 2.

The analysis can address whether external managers who are compensated based on assets or income choose higher-yielding properties when they diversify. Since their compensation contract may not explicitly accommodate for differences in risk, external managers may have a preference for assets with higher levels of both expected return and risk. To empirically test for this behavior among REIT managers, we modify the previous specification and allow the yield to vary with the external management indicator. Abstracting from our use of weighted-least-squares and annual intercepts, the benchmark specification is

$$
\text { Cash flows }=\beta \text { assets }+\varepsilon,
$$

so that $\beta$ is a measure of the cash-flow yield.

As above, we allow $\beta$ to vary with the indicator; therefore, the appropriate specification includes not the indicator itself but the interaction of the indicator with the propertymarket ("Main Street") value of the assets. ${ }^{1}$

Estimates of this specification are presented in the second column of Table 6 . The results provide little evidence that external managers choose projects with higher expected gross cash-flow yields. Although the coefficient is positive, it is insignificant at any traditional significance level.

The third specification presented in Table 6 augments the previous specification by including debt and debt multiplied by the management structure indicator. We include this specification for two reasons. First, this specification can be considered a test of robustness of our results to alternative functional forms. Second and more important, these additional variables become relevant for the analysis of the corporate expenses and cash flows below.

The results of this specification suggest dependence between investing and financing decisions. The coefficient associated with assets suggests a yield of 7.2 percent for unlevered, internally managed firms. However, the yield increases by 105 basis points for unlevered externally managed firms. Surprisingly, the coefficient associated with liabilities is positive and significant. This coefficient indicates that REITs with higher debt levels in their capital structures also hold assets with higher gross cash-flow yields, suggesting that leverage and asset risk are complimentary for our sample. However, this increase is pertinent only for internally managed REITs. For externally managed ones, an increase in debt increases gross cash-flow yields by only 77 basis points $(=3.19-2.42)$. We interpret these findings as weak evidence that internally managed REITs use debt selectively and issue debt to finance higher-yielding projects, while externally managed REITs issue debt indiscriminately.

\subsubsection{Corporate-level administration expenses}

Two deductions from gross cash flows determine net cash flows-alternatively called corporate-level cash flows or funds from operations (FFO). The deductions are interest 


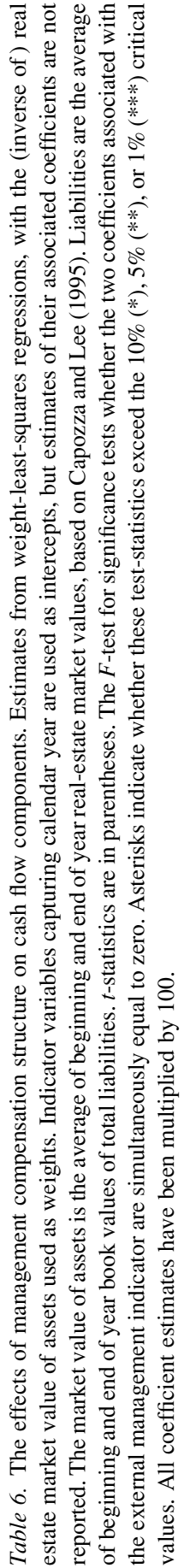

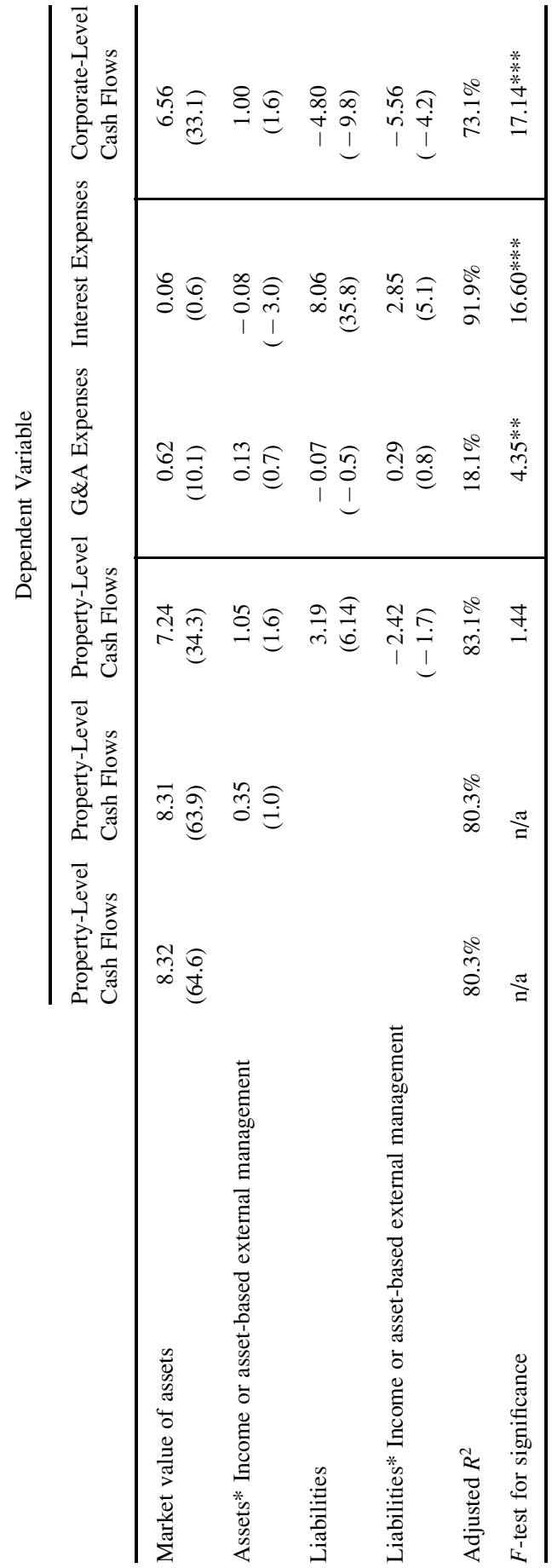


expenses, which we examine in the next subsection, and the cost of the corporate-level management team-that is, general and administrative (G\&A)-expenses, which we examine here. This measure includes corporate-level asset-management expenses (including salaries to the management team, filing and reporting costs) but excludes all property-level expenses (such as property management, maintenance, or taxes).

Consistent with the predictions and estimates in Capozza and Segum (1998a), there is strong evidence linking G\&A expenditures to assets under management. The coefficient associated with assets is 0.62 suggesting that, on average, G\&A expenditures, including compensation to managers, increases by $\$ 6.20$ for every $\$ 1,000$ increase in assets under management. In this specification, G\&A expenditures do not vary with debt. Thus, for internally managed trusts, G\&A varies with assets under management, regardless of how they are financed.

There is evidence that the relation differs for externally managed trusts. Although each of the two coefficients associated with the external advisor indicators is insignificant, they are jointly significant at the 5 percent level. These seemingly contradictory results strongly indicate the presence of multicolinearity and reflect the high correlation between the two variables. This high correlation in turn reflects that, for externally managed trusts, the dollar amount of debt in the capital structure is highly correlated with the dollar amount of assets under management, which is consistent with the evidence in Section 5.1.

Nonetheless, the joint significance of the two positive coefficients indicates that G\&A expenses, expressed as a fraction of assets or debt, are higher for externally managed trusts. For example, an internally managed trust that increased its asset base by $\$ 1,000$ while maintaining its leverage ratio (which averages 32.3 percent from Table 2) would increase its G\&A expenditures by $\$ 5.97(=1000 \times 0.62 \%-1000 \times 32.3 \% \times 0.07 \%)$. If the same trust were externally managed, the same asset base increase would result in an increase in G\&A of $\$ 8.44(=1000 \times[0.62 \%+0.13 \%]+1000 \times 42.9 \% \times$ $[-0.07 \%+0.29 \%])$, which is 25 basis points higher.

\subsubsection{Interest expenses}

The second expense subtracted from property-level cash flows to calculate cash flows available for shareholders is interest expense. We use the same functional form and set of independent variables in investigating the determinants of interest expense that we used in investigating gross cash flows and G\&A expenses. ${ }^{2}$

The fifth column of Table 3 contains estimates of parameters linking interest expenses to assets, liabilities, and managerial structure. The coefficient linking interest expense with the amount of debt 8.1 percent, can be interpreted as an estimate of the marginal cost of debt for internally managed trusts. Further, for such trusts, holding debt constant, increasing assets, and therefore reducing leverage have no significant impact on the marginal cost of debt. This suggests that, for these internally managed REITs, debt levels are low enough so that changes in leverage have no impact on the cost of debt.

In contrast, there is evidence that capital structure affects the cost of debt for externally managed firms. As above, holding debt constant, increasing the assets, and so reducing 
financial leverage reduce the marginal cost of debt. This is consistent with the joint hypothesis that the debt for externally managed trusts is risky and that leverage affects the premium charged.

Most important, however, is the coefficient associated with the indicator multiplied by debt. We interpret this coefficient as an estimate of the additional marginal cost of debt for externally managed REITs after controlling for levels of debt and assets (and, therefore, leverage). This economically and statistically significant coefficient suggests that these REITs pay interest rates on debt that are almost 3 percent higher than their internally managed counterparts.

Since we limit our examination to a single line of business and our model controls for the determinants of leverage, our methods inherently control for both business risk ${ }^{3}$ and financial risk. Our point estimates suggest that the typical cost of debt financing for externally managed REITs is around 11 percent and exceeds the current return on assets, which is under 9 percent. Managers who receive asset-based or property-level-incomebased compensation have incentives to issue debt (to increase the basis of their compensation) but have no incentives to do so at a fair market value. Indeed, since negotiating fair rates may require considerable effort for which the manager is not being compensated, debt contracts at supernormal rates are to be expected.

\subsubsection{Funds available to equity holders}

Consistent with the specifications used above for corporate-level expenses and interest expenses, we estimate a specification linking corporate-level cash flows (FFO) to assets, liabilities, and management form. The results, again using WLS and annual intercepts, are reported in the sixth column of Table 6 . The coefficient associated with the propertymarket value of assets can be interpreted as a net return-on-asset yield estimate. For reasons outlined above, this estimate of 6.56 percent equals the estimated gross cash-flow yield ( 7.24 percent) minus the marginal cost of G\&A expenses ( 0.62 percent) and minus the (insignificant) marginal impact of interest expenses $(-0.06)$. The coefficient associated with debt is negative, reflecting the interest expense. Note that the difference between these coefficients (1.76 percent) represents the marginal corporate-level profit available to internally managed trusts from issuing debt and investing the proceeds in real assets.

Of principal importance, however, is the link between management-compensation structure and cash flows available to shareholders. There is strong evidence that corporatelevel cash flows are adversely affected by external management. Specifically, increased debt use by externally managed trusts reduces corporate-level cash flows by 5.56 percent more than the use of debt by internally managed trusts. Further, the marginal corporatelevel spread to issuing debt and investing in real assets, which was +1.76 percent for internally managed trusts, is -2.8 percent $(=6.56+1.00-4.80-5.56)$. This last result suggests that externally advised REITs use excessive debt and the issue this debt at abnormally high rates. 


\section{Do abnormal interest costs explain it all?}

In the previous section, we provided evidence that externally advised trusts generate lower cash flows available to shareholders, primarily due to higher relative interest expenses. The primary objective of this section is to determine whether the underperformance of externally managed REITs can be attributed entirely to the indirect relationship between compensation structure and performance via interest costs or whether there exists any additional, direct relationship between structure and valuation after controlling for the higher debt charges.

\subsection{Abnormal interest costs}

As a first step, we construct a model of abnormal interest expense that does not explicitly include the organizational structure. To do so, we modify the interest expense specification presented in Table 6 by removing those variables related to managerial compensation structure. The results appear in the first two columns of Table 7. Consistent with previous results, the coefficients associated with the average of the beginning and end-of-year levels of debt outstanding indicate an average interest expense of around 8 percent of the book value of debt. The coefficient associated with assets in the second specification is insignificant and positive suggesting that, as in our discussion of Table 6 , the degree of leverage is not pertinent.

Of primary importance, however, are the residuals from these specifications, which we employ as our proxy for abnormal or unexpected interest expenses. Although we report results when residuals from the second specification are employed, the results are unchanged when we use the residuals from the first. Further, results are unchanged if we use, as our metric of abnormal interest expense, the residuals from the interest-expense specification from Table 6 and add back the products of the two structure-related variables and their estimated coefficients.

\subsection{Abnormal interest costs and relative value}

Section 4 provided a number of metrics demonstrating underperformance for the subsample of externally managed trusts. The metric we reported to demonstrate lower relative values was the ratio of the stock-market value of equity, to the underlying realestate value of equity. Here we employ a specification reported as a robustness test in Section 4.3, with stock-market values of equity as the dependent variable and propertymarket values of equity as an independent variable. Since this regression is cast in terms of dollars, it is convenient for addressing the impact of abnormal interest expenses.

In this framework, we estimate a relative discount by adding as an additional independent variable, the product of the indicator variable with the property-market variables. The results, reported in the first column of panel B in Table 7, indicate that internally managed trusts trade at a 13 percent premium over their intrinsic, or property- 


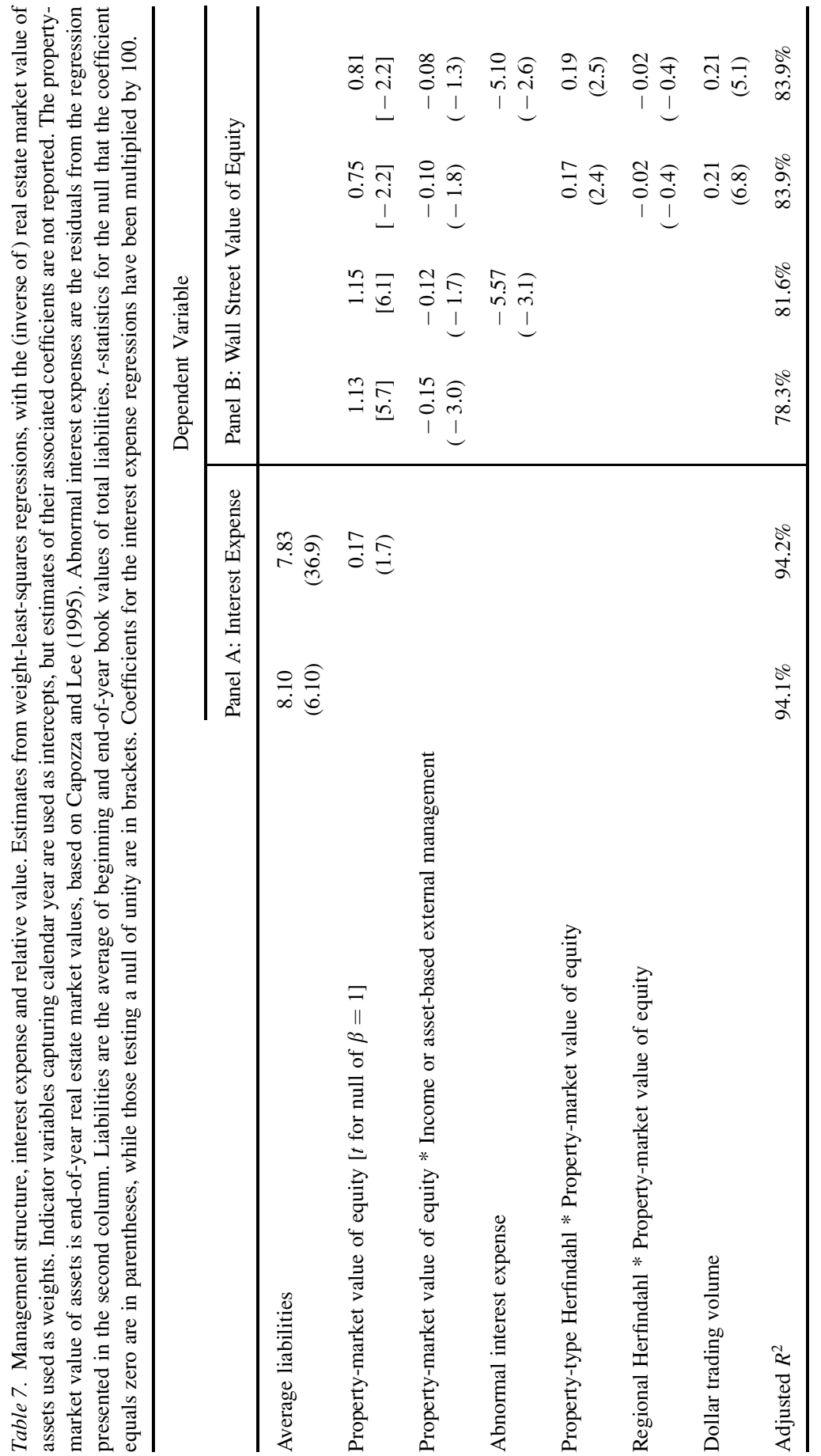


market net asset value. The $t$-statistic, reported in brackets, indicates that this coefficient is significantly above unity. We interpret this premium as reflecting the liquidity gains from securitizing illiquid real estate assets.

Of primary importance, however, is the coefficient associated with the product of assets and an external management indicator. Consistent with the evidence presented in Section 4.2, the estimated coefficient suggests that such trusts are discounted by about 15 percent.

To detect the valuation effects of excess interest expenses, we include the interest expense residual in the specification reported in the second column of panel B. Following Capozza and Seguin (1998a), we interpret this coefficient as investors' consensus belief about the net-present-value of a growth perpetuity. That is, if a trust pays an additional dollar in excess interest expense, investors rationally believe that such expenditure is not a unique occurrence for that year but is a signal of current and future cash outflows. In this framework, the coefficient equals $(1 / r-g)$, where $r$ and $g$ are the discount and growth rates of the perpetuity, respectively.

The coefficient associated with excess interest expense is estimated at -5.6 . Since surveys (e.g., Korpacz) indicate that a typical discount rate used by investors for real estate assets during this period was 12 to 14 percent, the coefficient is consistent with investors' valuing the excess interest as a perpetuity with a growth rate of -4 to -6 percent (e.g., $1 /(5.6)-0.12=0.06)$, suggesting a half-life of 11 to 17 years. Similarly, using the average interest yield on externally managed trust debt of 11 percent yields a decay rate of 7 percent and a half-life of over 10 years. These estimates suggest that investors value these trusts as if contemporaneous increases in excess interest costs have long-horizon cash-flow ramifications.

In this specification, which controls for excess interest expenses, the coefficient associated with externally managed trusts is smaller and becomes insignificant. ${ }^{4} \mathrm{We}$ interpret this as weak evidence that the avenue by which managerial compensation structure affects value is through the cost of debt.

In the following two columns, we repeat the analysis using a richer model of relative value. Specifically, following the suggestions of Capozza and Seguin (1998b), we include the focus of the asset base and the liquidity of the traded equity claims. Consistent with their findings, traded equity claims are more valuable, relative to the replacement value of the asset base, when the asset base has a more concentrated holding of property types, and/ or when the publicly traded equity is more liquid. However, more important are the estimates associated with the product of the indicator and equity. As before, accommodating excess interest expense reduces the magnitude and the significance of the coefficient associated with the product, again providing evidence that the primary avenue through which compensation managerial structure affects value is through the cost of debt.

\section{Summary and conclusions}

Our study is by no means the first to document that externally managed REITs underperform their internally managed counterparts. However, this study has shed much 
light on this puzzling regularity. To summarize our study, we review these contributions in ascending order of importance. First, unlike past studies, which use only ex post measures of underperformance, we examine both ex post and ex ante measures. Consistent with past studies, we find that, using stock return methods, externally advised trusts underperformed their internally managed counterparts. However, we show that this result holds even after controlling for differences in risk.

Second, we provide compelling evidence concerning an ongoing debate. Although previous work has acknowledged that equity claims to externally managed trusts had higher levels of systematic risk than claims to internally managed trusts, the source of this greater risk was never identified. To resolve this issue, we estimate "unlevered" or asset betas and find no discernible differences in asset or business risk between the two classes of trusts. Thus, we conclude that differences in risk are solely attributable to differences in financial risk.

Third, we use $q$-ratio analysis to determine whether the underperformance of externally managed trusts is partially or fully anticipated by shareholders. We find that the Wall Street or equity market value of trusts relative to the main street or property-market value of the trusts is lower for externally managed trusts, suggesting that underperformance is at least partially anticipated. Since investments even at these discounted values underperformed throughout, we conclude that any anticipation was incomplete.

Fourth, we demonstrate that externally managed trusts have greater financial leverage. The typical internally managed trust is financed with roughly one-third debt, while an externally managed trust has a capital structure with roughly 44 percent debt. We interpret this as evidence that managers compensated based on assets under management or property-level income have incentives to increase their compensation base by issuing debt and investing the proceeds in additional assets.

Corporate finance theory suggests that higher debt levels should not necessarily lead to lower valuations. Indeed, one of the fundamental axioms of corporate theory is that, in a tax-free world, value and capital structure should be completely irrelevant. However, such conclusions are reached only under the assumption of competitive markets, where debt contracts are negotiated at fair, risk-adjusted discount rates.

The fifth and most important result is that, for externally managed trusts, debt contracts are negotiated at excessive rates. Specifically, interest expenses are 285 basis points higher for externally managed trusts than for their internally managed counterparts, on average. Further such difference cannot be explained by differences in risk or leverage between the two classes of trusts. Indeed, our estimates indicate that when externally managed trusts borrow money and invest the proceeds in real assets, they borrow at rates that exceed the current yield they receive from the property assets.

Finally, we demonstrate that not only is excess interest expense one avenue through which managerial structure affects valuation and performance but that it may be the sole avenue. Specifically, when we examine the link between organization and value, we find a strong relationship when excess interest is ignored but an insignificant relationship when we include the impact of excess interest costs.

The existence of publicly traded REITs with both external and internal managers provides a unique opportunity to contrast the impact of managerial compensation structure 
while holding many other variables constant. The results of our experiment are clear and definitive. External advisers dramatically underperform their internally managed competitors and the underperformance can be traced primarily to their use (or abuse) of leverage and debt. Our results have a number of implications for the design of financial asset claims on real estate assets, for the design of managerial contracts, and for the speed at which the financial markets learn.

Given the magnitude of the underperformance of externally advised REITs, it would be surprising if investors did not learn of the differing performance of the two management structures, and, indeed, our evidence from $q$ ratios indicates that the relative underperformance of external management is at least partially anticipated in the pricing of REITs. However, subsequent events also provide evidence that learning occurred. First, the proportion of REITs that were externally advised has fallen significantly. During our sample period, the proportion of trusts that were externally managed fell from about half of the sample to about a quarter. This decline occurred both because existing REITs converted from external to internal management and because REIT IPOs were more likely to be internally managed.

A second reflection of the growing acknowledgment of the costs of external management can be found in a controversial recent trend in the industry: the consolidation of REITs and real estate companies into larger entities. Tax law in the early 1980s encouraged the proliferation of small RELPs and REITs. Their small-market capitalization necessitated the use of external advisors rather than internal managers. Once investors became aware of the poor relative performance of these small entities and valuations began to reflect performance differences, managers could create wealth by reorganizing into larger, internally managed REITs. Therefore, we attribute at least some of the recent wave of mergers and liquidations in the industry to a glaring need to rewrite badly misaligned management contracts that were more likely to be found among small REITs and RELPs with external management.

Finally, our results reemphasize the importance of incentives for managerial success and for investor returns. Our experiment using REIT industry data provides some of the starkest evidence on these issues and some of the most compelling evidence on the importance and magnitude of the links between executive compensation contracts and shareholder wealth.

\section{Acknowledgment}

We thank seminar participants at the University of Michigan, Rice University, University of Nebraska, Notre Dame, and the University of Pittsburgh for helpful comments.

\section{Notes}

1. Replacing the estimated property-market value of assets with book values gives similar results but with weaker fit statistics and coefficients closer to zero, thus suggesting measurement error bias. 
2. Absent an obvious alternative functional form, we employ this specification for an important econometric reason. Since the specifications for gross cash flows, net cash flows and the two corporate-level expenses use (1) the same dataset of independent variables and (2) identical functional form, differences in the impact of a factor on gross versus net cash flows can be readily traced and attributed to one of the two corporate-level expenses. The coefficient associated with a particular independent variable in the net cash-flow specification must equal the coefficient associated with that same variable in the gross cash-flow specification minus the coefficients in the interest and G\&A expense specifications (see Capozza and Seguin, 1998b).

3. Gyourko and Keim (1992) are unsuccessful in finding any systematic relation between equity factors and contemporaneous returns to the Russell-NCREIF appraisal-based index of property values. Similarly, Geltner (1989) can find no evidence of systematic risk associated with either the FRC or PRISA indices of property values, even when delays in updating property-value indices are explicitly modeled. Therefore, we assume that even if underlying property assets are subject to systematic factors, the cross-sectional variation of the systematic risk is insignificant.

4. The coefficient is insignificant and the $t$-statistic falls by 43 percent, even though the coefficient estimate is only 20 percent smaller than the previous specification. Although this situation is consistent with multicolinearity, and excess interest expense is correlated with the management structure indicator, we do not believe that multicolinearity is present for two reasons. First, we use excess interest expense and the product of the structure indicator and equity. Since externally managed trusts are both smaller and more highly levered, the correlation between excess interest expense and the product $(0.067)$ is lower than the correlation between excess interest expense and the indicator alone (0.112). Second, and more important, multicolinearity will reduce or eliminate the significance of all correlated coefficients, though the coefficients will remain jointly significant. In this case, the excess interest expense coefficient remains highly significant.

\section{References}

Bradley, M. J., D. R. Capozza, and P. Seguin. (1998). “'Dividend Policy and Cash Flow Uncertainty,'” Real Estate Economics 26(4), 555-580.

Cannon, S. E., and S. Vogt. (1995). "REITs and Their Management: An Analysis of Organizational Structure, Performance, and Management Compensation,'” Journal of Real Estate Research 10, 297-317.

Capozza, D. R., and S. Lee. (1995). "Property Type, Size, and REIT Value," Journal of Real Estate Research 10(4), 363-380.

Capozza, D. R., and P. Seguin. (1998a). “Managerial Style and Firm Value,’' Real Estate Economics 26(1), 131150.

Capozza, D. R., and P. Seguin. (1998b). “Focus Transparency and Value,', Real Estate Economics 27(4), 587619.

Finnerty, J. E., and H. Y. Park. (1991). Managerial Compensation and the Characteristics of Firms: The Case of REITs. Working Paper, University of Illinois.

Geltner, D. (1989). "Estimating Real Estate's Systematic Risk from Aggregate-Level Appraisal-Based Returns,' Journal of the American Real Estate and Urban Economics Association 17, 463-481.

Gyourko, J., and D. B. Keim. (1992). “What Does the Stock Market Tell Us About Real Estate Returns?”' Journal of the American Real Estate and Urban Economics Association 20, 457-486.

Hendershott, P., and E. Kane. (1995). “U.S. Office Market Values During the Past Decade: How Distorted Have Appraisals Been?', Real Estate Economics 23(2), 101-116.

Howe, J. S., and J. D. Shilling. (1990). “REIT Advisor Performance,’' AREUEA Journal 18(4), 479-499.

Hsieh, Cheng-Ho, and C. F. Sirmans. (1991). "REITs as Captive-Financing Affiliates: Impact on Financial Performance," Journal of Real Estate Research 6(2), 179-189.

Jenkins, J. W. (1980). “Incentive Compensation and REIT Financial Leverage and Asset Risk,' Financial Management 9(1), 81-87.

Kalay, A. (1980). 'Signaling, Information Content and the Reluctance to Cut Dividends,' Journal of Financial and Quantitative Analysis 2, 855-869. 
Karpoff, J., and R. Walking. (1988). "Short-Term Trading Around Ex-Dividend Days: Additional Evidence," Journal of Financial Economics 21, 291-298.

Lang, L., and R. Stulz. (1994). "Tobin's q, Corporate Diversification, and Firm Performance," Journal of Political Economy 102, 1248-1280.

Lindenberg, E. B., and S. A. Ross. (1981). "Tobin's $q$ Ratio and Industrial Organization," Journal of Business $54(1), 1-32$.

Sagalyn, L. B. (1996). “Conflicts of Interest in the Structure of REITs,” Real Estate Finance 13(2), 34-51. 